\title{
Peran Orang Tua dan Wali Kelas Dalam Pembentukan Afektif Siswa Di SD Negeri Nusa Harapan Permai Kota Makassar
}

\author{
Internalization of The Value Toraja Cultural In The Development Of Teaching \\ Materials To Read Indonesian In SD Tana Toraja District
}

\author{
Henderina Oualeng ${ }^{1}$, Mas'ud Muhammadiah ${ }^{2}$, Sundari Hamid ${ }^{2}$ \\ ${ }^{1}$ Dinas Pendidikan Kabupaten Alor \\ ${ }^{2}$ Program Studi Studi Pendidikan Dasar, Program Pascasarjana, Universitas Bosowa
}

E-mail: henderinaoualeng@yahoo.com

Diterima: 14 Januari 2021/Disetujui 07 Juni 2021

\begin{abstract}
Abstrak. Tujuan penelitian ini adalah untuk mengetahui sejauhmana peran orangtua dan wali kelas dalam pembentukan afektif siswa dan untuk mengetahui kendala-kendala yang dihadapi orang tua dan wali kelas di Sd negeri Nusa harapan permai kota Makassar.Jenis penelitian ini adalah penelitian kualitatif, metode penelitian yang digunakan adalah metode deskriptif dengan pendekatan kualitatif, data dalam penelitian ini berupa data dari hasil wawancara dengan informan dan dan hasil observasi/pengamatan, pengumpulan data menggunakan lembar pedoman wawancara dengan orangtua dan wali kelas dan lembar observasi afektif siswa. Hasil penelitian menunjukkan bahwa sudah ada peran orangtua dengan cara mengasuh dan mendidik anak, bekerjasama dengan wali kelas, kendala yang dihadapi orangtua adalah karena kesibukan dalam bekerja sehingga sulit dalam membagi waktu dalam mendidik anak sedangkan kendala guru adalah masih banyak siswa yang malas dan masih ada orangtua yang tidak memperdulikan kesiapan anak ke Sekolah.
\end{abstract}

Kata Kunci: Orangtua, Wali Kelas, Efektif

\begin{abstract}
The purpose of this study was to determine the role of parents and homeroom teachers in the affective formation of students and to determine the obstacles faced by parents and homeroom teachers in SD Negeri Nusa Harapan Permai, Makassar City. This type of research is qualitative research. The research method used is descriptive method with a qualitative approach. The data in this study are in the form of data from interviews with informants and observations. Data collection uses interview guidelines with parents and homeroom teachers and student affective observation sheets. The results show that there is already a role of parents by caring for and educating children, in collaboration with homeroom teachers, the obstacles faced by parents are due to busy work so that it is difficult to manage time in educating children, while the teachers' obstacles are that there are still many students who are lazy and there are still parents who do not care about children's readiness to go to school.
\end{abstract}

Keywords: Parents, Homeroom Teacher, Affective

\section{Pendahuluan}

Pendidikan adalah usaha sadar dan terencana untuk mewujudkan suasana belajar dalam proses pembelajaran peserta didik agar secara aktif mengembangkan potensi dirinya untuk memiliki kekuata spiritual keagamaan, pengendalian diri, kepribadian, kecerdasan, akhlak mulia, serta keterampilan yang diperlukan dirinya dan masyarakat (UU Sisdiknas No. 20 Tahun 2003). Pendidikan di sekolah merupakan lanjutan atau pengembangan pendidikan yang telah diberikan oleh orangtua terhadap anak-anaknya dalam keluarga, dimana hal tersebut dikarenakan beberapa faktor antara lain, a) keterbatasan pengetahuan orangtua, b) kesempatan waktu, c) perkembangan anak, d) lingkungan kehidupan di sekolah merupakan jembatan bagi anak, yang menghubungkan kehidupan dalam keluarga dengan kehidupan dalam masyarakat kelak

Peran orangtua sangatlah penting dalam pendidikan, karena pendidikan yang pertama dan utama dimulai dari lingkungan keluarga dan orangtua menjadi kunci utama terjadinya sebuah pendidikan dalam keluarga itu sendiri. Marijan (2012) dan menurut anggono (2011) kebutuhan dasar anak meliputi kebutuhan fisik-biomedis (asuh), kebutuhan emosi/kasih sayang (asih), dan kebutuhan akan stimulasi mentaluntuk proses belajar pada anak (asah). Dalam pendidikan di sekolah perlu adanya hubungan yang baik dengan orangtua peserta didik agar terjadi keselarasan pembelajaran di sekolah dan di rumah. Partisipasi orangtua sangat penting demi terciptanya kelancaran dalam pembelajaran.

Jainuddin (2019), bahwa guru merupakan salah satu faktor penentu keberhasilan pada sebuah proses belajar mengajar. Peran wali kelas dalam hal ini sangat penting berpengaruh dalam proses pendidikan, karena peran wali kelas sangat dominan dalam pengelolaan kelas dan kemampuan mengajar seorang guru. Darmawan dkk (2021) mengemukanan Guru yang mempunyai tugas sebagai wali kelas harus mempunyai kompetensi profesional sehingga terciptalah proses belajar yang efektif, efesien, dan dapat mengatasi permasalahan dalam pengelolaan kelas. Wali kelas adalah guru yang diberi kepercayaan oleh kepala sekolah untuk mengelola kelas dan mengendalikan siswa dalam proses belajar mengajar, oleh karena itu peran wali kelas sangat penting dalam pengelolaan kelas dalam membinah dan mengarahkan para siswanya dalam mencapai 
prestasi yang diinginkan. Tugas dan fungsi wali kelas dalam hal ini adalah mengerakkan siswanya, mempengaruhi, membimbing, memotivasi, mengarahkan, menciptakan kondisi dan lingkungan yang kondusif satu sama lain sehingga kelas itu menjadi komunitas belajar yang dapat maju bersama dalam proses pembelajaran.

Sesuai dengan uraian di atas dapat dimengerti bahwa peran orangtua dan wali kelas dalam pembentukan afektif di sekolah dan di rumah itu sangat penting karena membantu kelancaran dan keefektifan pembelajaran siswa. Sehingga mengantarkan siswa kepada minat, dan semangat yang kuat untuk lebih giat belajar. Hasil kinerja wali kelas ini terutama bisa dilihat bagaimana ia dapat menjadi mediator bagi kelas sebagai sebuah komunitas pembelajaran bersama (Jainuddin, 2020). Wali kelas menjadi guru bidang studi tertetu, namun mereka mendapatkan tugas tambahan sebagai penanggungjawab dinamika pembelajaran di dalam kelas yang paling menonjol adalah menjadi semacam kepala keluarga dalam suatu kelas, ini berarti ia bertanggungjawab terutama menciptakan kondisi lingkungan yang kondusif.

Suatu kondisi belajar yang optimal dapat tercapai jika wali kelas mampu mengatur anak didik, proses pembelajaran, dan sarana mengajar serta mengendalikannya dalam suasana yang menyenangkan . untuk mencapai tujuan pengajaran dan jga hubungan interpersoanl yang baik antara guru dan anak didik. SD Negeri Nusa harapan Permai terletak di kompleks BTN Nusa Harapan permai, Kecamatan Biringkanaya kota Makassar, dengan jumlah siswa secara keseluruhan 162 yang terdiri atas laki-laki 66 dan perempuan 96, sedangkan secara khusus siswa kelas V ada 27 orang yang terdiri atas laki-laki 9 orang dan perempuan 18 orang. Jumlah guru adalah 13 orang yang terdiri dari 9 guru perempuan dan 4 guru laki-laki.

Berdasarkan observasi awal yang peneliti lakukan di sekolah terdapat beragam kondisi dan permasalahan yang dihadapi oleh masing-masing wali kelas, pada kelas $\mathrm{V}$ belum secara maksimal adanya peran wali kelas dalam pembentukan afektif. Oleh karena kurangnya komunikasi antara wali kelas dan orangtua tentang perkembangan peserta didik, sikap dan nilai-nilai yang nampak dalam peserta didik belum menunjukkan keselarasan dalam pola pembelajaran dari rumah dan di sekolah. Masalah lain yang ditemukan adalah bahwa rata-rata orangtua berasal dari keluarga kurang mampu sehingga sulit membagi waktu bagi anak dan mendampingi untuk mengetahui perkembangan anak bahkan berdiskusi dengan guru tentang perkembangan anak di sekolah dan di rumah.

Berdasarkan uraian di atas peneliti tertarik untuk melakukan penelitian dengan judul" Peran Orang Tua Dan Wali Kelas Dalam Pembentukan Afektif Siswa Di SD Negeri Nusa Harapan Permai Kota makassar dengan Tujuan penelitian ini adalah untuk mengetahui sejauhmana peran orangtua dan wali kelas dalam pembentukan afektif siswa dan untuk mengetahui kendala-kendala yang dihadapi orang tua dan wali kelas di SD negeri Nusa harapan permai kota Makassar.

\section{Metode Penelitian}

Metode penelitian yang digunakan adalah metode deskriptif dengan pendekatan kualitatif. Penilaian kualitatif adalah suatu pendekatan penelitian yang mendeskripsikan situasi sosial sesuai kenyataan yang benar dibentuk berdasarkan kata-kata berdasarkan situasi alamiah (Satori Dan Komariah 2012).

Lokasi penelitian merupakan tempat yang dipilih sebagai lokasi yang ingin diteliti untuk memperoleh data yang diperlukan yaitu SD Negeri Nusa harapan permai sebagai lokasi penelitian, yang terletak di kompleks BTN Nusa Harapan Permai Kota makassar, Kecamatan Biringkanaya Kota Makassar.

Data penelitian ini berupa data dari hasil wawancara dengan informan dan hasil observasi /pengamatan di SD Negeri Nusa Harapan Permai. Sumber data dalam penelitian ini adalah orangtua siswa kelas V dan wali kelas V SD Negeri Nusa harapan Permai. Teknik pengumpulan data dalam penelitian ini adalah wawancara, observasi dan dokumentasi. wawancara ini dilakukan terhadap orangtua siswa kelas $\mathrm{V}$ dan wali kelas $\mathrm{V}$ dengan menggunakan pedoman wawancara semi terstandar/bebas terpimpin yang telah dilakukan oleh penulis. Selanjutnya peneliti juga melakukan Pengamatan/observasi kepada siswa dengan membagikan lembar observasi kepada siswa, dan juga penulis mengumpulkan data dengan mencatat data-data yang sudah ada, termasuk profil sekolah dan data siswa.

Teknik analisis data yang telah dikumpulkan melalui wawancara akan dianalisis dengan menggunakan teknik analisis data sebagai berikut:

1. Reduks data

Mereduksi data berarti merangkum, memilih hal-hal yang pokok, memfokuskan pada hal-hal yang penting dicari tema dan polanya. Dengan demikian data yang telah direduksi akan memberikan gambaran yang jelas dan mempermudah peneliti untuk melakukan pengumpulan dan selanjutnya, mencarinya bila diperlukan.

2. Penyajian data

Setelah data direduksi, maka langkah selanjutnya adalah penyajian data, melalui penyajian data tersebut, maka data terorganisasikan, tersusun dalam pola hubngan, sehingga akan mudah dipahami.

3. Penarikan kesimpulan/verivikasi

Langkah ketiga dalam analisis data kualitatif adalah penarikan kesimpulan,. Kesimpulan yang dikemukakan dalam penelitian kualitatif, didukung oleh bukti-bukti yang valid dan konsisten saat peneliti kembali ke lapangan mengumpulkan data, maka kesimpulan yang dkemukakan merupakan kesimpulan kredibel, dan dapat menjawab rumusanmasalah yang dirumuskan.

Dalam penelitian ini akan melakukan pengecekan keabsahan data melalui:

1. Kreadibilitas/keterpercayaan untuk menguji kredibilitas penelitian maka diukur kebenaran data yang dikumpulkan, apakah menggambarkan konsep peneliti dengan hasil penelitian (Satori dan Komariah, 2012),

2. Defendabilitas/ketergantungan dilakukan dengan mengaudit keseluruhan proses penelitian mulai dari menentukan masalah, memasuki lapangan, menentukan sumber data, melakukan analisis data, melakukan uji keabsahan data dan membuat kesimpulan (Satori dan komariah, 2012),

3. Konfirmabilitas/kepastian dilakukan dengan tujuan bahwa data yang diperoleh dapat dilacak kebenarannya dan sumber 
informannya jelas yang dilakukan dengan nmelakukan sumber check, triangulisasi, pengamatan ulang atas rekaman, pengecekan kembali (Satori/keteralihan)

4. Transferabilitas/keteralihan dilakukan dengan memberikan informasi secara lengkap, sistematis dan dapat dipercaya dan hasil penelitian dapat diterapkan pada lokasi penelitian atau pada lokasi lain dengan masalah yang sama (satori dan komariah, 2012),

\section{Hasil dan Pembahasan}

Peran orang tua dalam tumbuh kembang anak sangat dibutuhkan apalagi anak-anak yang masih membutuhkan pendampingan seperti anak-anak pada usia sekolah dasar.

a) Parenting (membimbing dan mengasuh anak)

Pengasuhan terhadap anak tidak dapat diabaikan karena menyangkut dengan tumbuh dan kembang anak. Pengabaian terhadap anak dapat mengganggu proses tumbuh kembang itu sendiri. Berdasarkan pertanyaan bagaimana Bapak/Ibu memberikan reward/penghargaan pada anak? Dari 12 orangtua ada 8 orangtua yang menyatakan bahwa mereka memuji anak ketika anak bersikap baik dan taat, 1 orangtua menyatakan memeluk dan mencium apabila anak berlaku baik, membelikan barang-barang seperti hp, tas, buku, sepatu, termasuk seragam sekolah selain itu memberikan barang kesukaan, memberikan uang jajan, makan di luar, menambah uang tabungan (bukan uang jajan).

b) Communicating (membangun komunikasi dengan Anak)

Salah satu peran orangtua dalam membentuk afektif anak adalah dengan cara membangun komunikasi yang baik dengan anak. Dari hasil wawancara bahwa orangtua membagun komunikasi dengan anak di rumah secara baik, hanya karena covid 19 dan 5 orangtua menyatakan bahwa lebih banyak menghabiskan waktu dengan bekerja sehingga secara intens waktu anak dengan orangtua sangat kurang, termasuk komunikasi yang dibangun untuk mengontrol afektif anak. Cara orangtua menjalin komunikasi dengan guru yaitu mendapatkan informasi dari guru tentang informasi penting melalui HP/handphone karena saat ini pandemic covid sehingga komunikasi yang dibanguna dalah melalui HP/handphone selain itu ada juga pertemuan/rapat guru dan orangtua di sekolah seperti saat kenaikan kelas atau penerimaan raport siswa.

c) Volunteering (sukarela)

Orangtua memiliki peran yang sangat penting dalam pembentukan afektif siswa salah satunya adalah mendukung kemajuan sekolah dengan cara selalu hadir dalam kegiatan-kegiatan sekolah seperti pertemuan orangtua dan wali kelas, selain itu membantu guru dalam mengajar dan mendampingi anak dalam belajar di rumah.

d) Learning at Home (belajar di rumah)

Pendampingan terhadap anak merupakan hal yang sangat penting saat suasana pandemi covid karena guru tidak mengajar secara penuh di sekolah seperti biasanya namun lebih banyak memberikan tugas dan belajar secara online sehingga pembelajaran di rumah dan sekolah menjadi tanggungjawab orangtua juga.

e) Desicion Making (Mengambil keputusan)

Orangtua sebagai pengambil keputusan menyangkut dengan anak. Orangtua dapat berkata ya dan tidak pada anak tetapi juga dapat memberikan anak ruang untuk anak dapat berkembang secara baik secara natural.

f) Collaborating with Community (berkolaborasi dengan komunitas)

Kerjasama antara orangtua dengan sekolah menjadi hal yang sangat penting. Berdasarkan hasil wawancara bahwa kerjasama baik yang dibangun antara guru dan orangtua adalah melakukan komunikasi dengan guru melalui HP/Handphone agar dapat mengontrol perkembangan anak oleh karena pembelajaran saat ini menggunakan pembelajaran online.

Wali kelas memegang peranan penting untuk bekerjasama dengan orangtua dalam membangun hubungan yang baik selain itu berkomunikasi dengan baik agar afektif anak dapat dibentuk sesuai usia dan kematangan anak. Peranan wali kelas dapat dideskripsikan sebagai berikut:

a. Mengetahui bagaimana karakteristik umum siswa dibawah perwalian Peran guru adalah memahami karakteristik anak karena menjadi wali siswa.

b. Peran wali kelas dalam bekerja sama dengan orang tua dalam proses pendampingan peserta didik.

c. Peran menjalin komunikasi yang baik dengan orang tua.

d. Kendala-kendala apa yang dihadapi wali kelas dalam pembentukan afektif siswa?

Berdasarkan pengamatan melalui siswa bahwa 55\% siswa sangat setuju orangtua memberikan nasihat di rumah, $40 \%$ siswa setuju orangtua memberi nasihat di rumah dan 5\% siswa menyatakan orangtua kadang-kadang memberikan nasehat kepada mereka saat di rumah dan tidak ada orangtua yang jarang atau tidak pernah memberikan nasehat saat anak berada di rumah.

Berdasarkan pengamatan melalui siswa bahwa 55\% siswa setuju orangtua membabtu mengerjakan PR di rumah, $40 \%$ siswa menyatakan orangtua kadang-kadang membantu mengerjakan PR di rumah dan tidak ada orangtua yang jarang atau tidak pernah membantu mengerjakan PR saat anak berada di rumah. Jadi tidak semua orangtua membantu anak belajar di rumah.

Berdasarkan pengamatan melalui siswa bahwa $10 \%$ siswa sangat setuju orangtua membantu mengajar anak di luar jam sekolah atau di rumah, $20 \%$ siswa setuju orangtua membantu mengajar anak di luar jam sekolah atau di rumah dan $70 \%$ siswa menyatakan orangtua membantu mengajar anak di luar jam sekolah atau di rumah, selain itu tidak ada orangtua yang jarang atau tidak pernah membantu mengajar anak di luar jam sekolah atau di rumah. 
Berdasarkan pengamatan melalui siswa bahwa ada 35\% siswa sangat setuju orangtua mengajarkan sikap disiplin pada anak saat anak berada di rumah, $65 \%$ siswa setuju orangtua memberi nasihat di rumah orangtua mengajarkan sikap disiplin pada anak saat anak berada di rumah, dan tidak ada orangtua yang kadang-kadang, jarang atau tidak pernah memberikan nasihat saat anak berada di rumah.

Berdasarkan pengamatan melalui siswa bahwa $80 \%$ siswa sangat setuju orangtua memberikan teladan bagi mereka di rumah, 20\% siswa setuju orangtua memberikan teladan bagi mereka di rumah dan tidak ada orangtua yang kadang-kadang, atau jarang atau tidak pernah memberikan teladan saat anak berada di rumah.

Berdasarkan pengamatan melalui siswa bahwa $\%$ siswas angat setuju orangtua memberikan reward/penghargaan atau pujian, $70 \%$ siswa setuju orangtua memberi reward/penghargaan atau pujian dan $25 \%$ siswa menyatakan orangtua kadangkadang memberikan reward/penghargaan atau pujian dan tidak ada orangtua yang jarang atau tidak pernah memberikan reward/penghargaan atau pujian.

Berdasarkan pengamatan melalui siswa bahwa15\% siswa sangat setuju orangtua melatih anak percaya diri, $80 \%$ siswa setuju orangtua melatih anak percaya diri dan tidak ada orangtua yang kadang atau jarang atau tidak pernah melatih anak percaya diri.

Berdasarkan pengamatan melalui siswa bahwa 10\% siswa sangat setuju orangtua mengajarkan tanggungjawab di rumah, $70 \%$ siswa setuju orangtua mengajarkan tanggungjawab di rumah dan $20 \%$ siswa menyatakan orangtua kadang-kadang mengajarkan tanggungjawab di rumah dan tidak ada orangtua yang jarang atau tidak pernah mengajarkan tanggungjawab di rumah.

Berdasarkan pengamatan melalui siswa bahwa 60\% siswa sangat setuju orangtua mengajarkan sopan santun pada mereka, $40 \%$ siswa setuju orangtua orangtua mengajarkan sopan santun pada mereka, dan tidak ada orangtua yang jarang atau kadang atau tidak pernah memberikan orangtua mengajarkan sopan santun pada mereka.

Berdasarkan pengamatan melalui siswa bahwa 25\% siswa sangat setuju orangtua mengajarkan kejujuran pada mereka, $75 \%$ siswa setuju orangtua mengajarkan kejujuran pada mereka dan tidak ada orangtua yang jarang atau tidak pernah mengajarkan kejujuran pada mereka

Berdasarkan pengamatan melalui siswa bahwa $100 \%$ siswa setuju Wali Kelas memberikan nasihat bagi mereka walaupun tidak semua sangat setuju. Berdasarkan pengamatan melalui siswa bahwa $100 \%$ siswa setuju Wali Kelas memberikan teladan bagi mereka walaupun tidak semua sangat setuju.

Berdasarkan pengamatan melalui siswa bahwa $85 \%$ siswa sangat setuju Wali Kelas memberikan hukuman saat siswa berbuat kesalahan, 15\% siswa menyatakan Wali Kelas kadang-kadang memberikan hukuman saat siswa berbuat kesalahan dan tidak ada Wali Kelas yang jarang atau tidak pernah memberikan hukuman saat siswa berbuat kesalahan.

Berdasarkan pengamatan melalui siswa bahwa 90\% siswa setuju Wali Kelas memberikan reward/penghargaan, 10\% siswa menyatakan Wali Kelas kadang-kadang member reward/penghargaan.

Berdasarkan pengamatan melalui siswa bahwa 90\% siswa setuju Wali Kelas mengajarkan anak belajar kejujuran, $10 \%$ siswa sangat setuju Wali Kelas mengajarkan anak belajar kejujuran. Berdasarkan pengamatan melalui siswa bahwa $15 \%$ siswa sangat setuju Wali Kelas mengajarkan disiplin, $85 \%$ siswa setuju Wali Kelas mengajarkan disiplin.

Berdasarkan pengamatan melalui siswa bahwa 5\% siswa sangat setuju Wali Kelas mengajarkan dan melatih percaya diri anak, $80 \%$ siswa setuju Wali Kelas mengajarkan dan melatih percaya diri anak dan 15\% siswa menyatakan Wali Kelas kadang-kadang mengajarkan dan melatih percaya diri anak.

Berdasarkan pengamatan melalui siswa bahwa15\% siswa sangat setuju Wali Kelas mengajarkan sopan santun, 85\% siswa setuju Wali Kelas mengajarkan sopan santun. Berdasarkan pengamatan melalui siswa bahwa $20 \%$ siswa sangat setuju Wali Kelas komunikasi dengan orangtua atau sebaliknya, 70\% siswa setuju Wali Kelas komunikasi dengan orang tua atau sebaliknya dan 10\% siswa menyatakanWali Kelas kadang-kadang komunikasi dengan orangtua atau sebaliknya. Berdasarkan pengamatan melalui siswa bahwa 25\% siswa sangat setuju Wali Kelas mengajarkan ajaran agama seperti sholat, ketaatan, kejujuran, 75\% mengajarkan ajaran agama seperti sholat, ketaatan, kejujuran

Pendidikan merupakan kebutuhan penting dalam kehidupan seseorang, tanpa pendidikan maka seseorang bias saja ketinggalan dalam segala aspek kehidupan baik itu secara sosial, mental, ekonomi maupun spiritual. Hasil penelitian menunjukkan bahwa orangtua menjalankan tugas sebagai orangtua dalam memenuhi kebutuhan fisik, namun ada juga kebutuhan secara psikis seperti kebutuhan akan rasa nyaman masih sangat kurang, komunikasi dengan anak masih sangat kurang karena kebanyakan orangtua bekerja dan sulit membagi waktu namun dalam hal mendukung kegiatan sekolah orangtua berperan karena membantu guru dalam mendidik anak menjadi pribadi yang taat beribadah, memiliki kejujuran sehingga visi sekolah dapat tercapai, selain itu pembelajaran di rumah menjadi tanggungjawab orangtua. Oleh karena pengaruh lingkungan sehingga terkadang anak sulit untuk diatur sehingga menyebabkan orangtua kadang sulit mengambil keputusan sehingga harus melibatkan guru dalam hal menasehati tetapi karena suasana pandemi covid sehingga memudahkan adanya komunitas media yang dapat menghubungkan orangtua dengan guru untuk meningkatkan komunikasi dan juga pengawasan terhadap belajaranak di rumah (Danin, 2010).

Peran guru wali kelas menjadi hal yang sangat membantu orangtua dalam pembentukan kemampuan anak terutama afektif siswa. Wali kelas selalu menasehati dan mengajarkan hal-hal yang baik bahkan menjadi teladan bagi siswa. Memahami karakteristik anaks ehingga dapat mengarahkan anak dalam berperilaku, berpakaian maupun belajar.

Peran dalam kerjasama dan komunikasi dengan orangtua masih bersifat program rutin seperti berkomunikasi saat anak diantar ke sekolah, berkomunikasi saat orangtua terima raport siswa dan berkomunikasi dalam grup sosial untuk mengetahui perkembangan belajar anak.

Kerjasama antara orangtua dan guru atau sekolah merupakan bentuknyata relasi yang dibangun atau dicipta agar komunikasi tidak terputus terutama melalui kominitas online untuksaling mendukung. 


\section{Kesimpulan dan Saran}

Hasil penelitian dapat disimpulkan bahwa orangtua telah menjalankan peran mereka dengan baik walaupun kurang dalam pendampingan dengan anak di rumah karena terkendala dengan kesibukan orangtua, kemampuan orangtua serta anak yang sulit diatur karena pengaruh lingkungan. Wali kelas melakukan peran secara baik namun kendala ketidakdisiplinan peserta didik, ketidaktaatan serta kurang perhatian orangtua terhadap anak menjadi hambatan. Peran komunikasi dan Kerjasama menjadi hal yang sangat penting dalam menjalin hubungan dengan wali kelas sehingga hal-hal yang menjadi penghambat dapat diatasi. Orangtua agar lebih memberikan perhatian dan pendampingan dengan anak saat anak berada di rumah. Wali kelas agar lebih proaktif dalam berkomunikasi dengan orangtua karena orangtua memiliki banyak kesibukan dan kurang mendampingi dengan anak di rumah sehingga perkembangan anak dalam belajar tidak meningkat secara merata. Kepada pihak sekolah agar mempunyai rancangan program yang dapat melibatkan orangtua dalam mendukung kegiatan sekolah sehingga terbangun kerjasama yang baik

\section{Daftar Pustaka}

Aan Komariah, Djam'an Satori. (2012). Metode Penelitian Kualitatif. Bandung: Alfabeta.

Anggono, Toha. 2011. Materi Pokok Metode Penelitian. Jakarta: Universitas Terbuka

Danim, Sudarwan. 2010. Profesionalisasi dan Etika Profesi Guru. Bandung: Alfabeta.

Darmawan, F. A., \& Jainuddin, J. (2021). Augmented Reality-based Mathematics Worksheet for Online Learning During Covid-19 Pandemic. Indonesian Journal of Educational Studies, 23(2), 81-90.

Depdiknas .2003. Undang-undang RI No.20 tahun 2003.tentang sistem pendidikan nasional

Edisi keenam. Jakarta. Erlangga.

Jainuddin, J. (2019). Peningkatan Hasil Belajar Matematika Melalui Latihan Menyelesaikan Soal Secara Sistematis Pada Siswa Kelas XI. IPA1 SMA Negeri 2 Sungguminasa. Klasikal: Journal Of Education, Language Teaching and Science, 1(3), 44-52.

Jainuddin, J., \& Sirajuddin, S. (2020). Pengaruh Minat dan Kedisiplinan Siswa dengan Gaya Kognitif Field Indefendent terhadap Hasil Belajar Matematika Siswa SMK Farmasi Yamasi Makassar. Delta-Pi: Jurnal Matematika dan Pendidikan Matematika, 9(2).

Marijan. 2012. Metode Pendidikan Anak. Yogyakarta: Sabda Media.

Model Addie. Jakarta: Kencana, 2014.

Ormrod, Jeanne Ellis, 2009. Psikologi Pendidikan.Membantu Siswa Tumbuh dan Berkembang. Jilid 1

Petriani, E., \& Ananda, A. (2018). Peran Dan Fungsi Wali Kelas Dalam Pembinaan Perilaku Siswa Di

Pribadi, A Benny. Desain dan Pengembangan Program Pelatihan Berbasis Kompetensi: Implementasi

Sardiman. 2007. Interaksi dan Motivasi Belajar Mengajar. Jakarta: PT. Raja GrafindoPersada.

Slameto. 1995. Belajar dan Faktor-faktor yang Mempengaruhi. Jakarta: Rineka Cipta.

Smp Negeri 33 Padang. Journal of Civic Education, 1(3), 289-296. 